\title{
Emanation of Beauty and Love in Hafez's Sonnets
}

\author{
Ebrahim Rhimi Zanganeh \\ Assistant professor \\ Razi University, Faculty of Arts, Persian Department, \\ Post code: 6714967346, Kermanshah, Iran. \\ E-mail: erahimi2009@yahoo.com \\ Phone No: +989183301277 \\ Noorbakhsh Hooti \\ Associate professor, \\ Razi University, Faculty of Arts, English Department, \\ Post code: 6714967346, Kermanshah, Iran. \\ E-mail: nhooti@yahoo.com \\ Phone No: +989125935460

\section{Babakhani, Tahereh} \\ M.A. student of Persian Language and Literature, \\ Islamic Azad University of Kermanshah, Iran
}

\section{Doi:10.5901/mjss.2013.v4n2p227}

\begin{abstract}
Inherent beauty in the light radiation of the Holy essence of God, conveying through the names, attributes, creatures and love, is an issue that initially has been observed in the great mystics' perspectives. The aesthetes have also demonstrated the main principles of this school of thought in their works. Emanation of the Holy essence of God through his names and beautiful attributes is manifested in the abundant mysterious pages of the mystical literature; these concepts have emerged along with the sensational words and phrases, which are about seduction, cute coquetry and other features of the beloved in the Hafez's poetic works. Thus, the present study aims at investigating these pearlike concepts under a new interpretation.
\end{abstract}

Key words:Hafez, Beauty, Love, Mysticism, Emanation, Divine Attributes, Romance

\section{Introduction}

In Iranian Lyric literature, beauty is one of the most evident issues which has the highest contribution to the poet's sense of concerns and seeking. Despite severe oppositions, advocates of this school established a creed known as aesthetics.

Looking after the beauty is innate in a way that this tensile strength and effort has nurtured love within itself. Love is a partial matter, since this has repeatedly been quoted and they need not to be introduced.

The history and the act of appreciating beauty appeared prior to human beings, yet it is independent. Wisdom, intellect and soul are divine gifts in human; however, desire for beauty which leads to love is a gentle blessing which adorns wisdom and intellect. Hence, everything even wisdom, intellect, and soul seem worthless without love.

All aesthetic poets and mystics are children of the love of beauty that God has created. Hafez is also under the influence of this intellectual and ideological creed. He loves endless elements, since seizing them is impossible, and they deserve love and appreciation.

The present article aims at investigating the spiritual and temporal dimensions of these inaccessible endless from Hafez's perspective. 


\section{School of Aestheticism}

Using the achievements of Greek philosophy and Eastern illumination in general and employing ancient wisdom in particular, during the first centuries of Islam, the school of aestheticism was established in Iranian-Islamic Sufism by an Iranian initiative person called Abuhelman1. Using Qur'anic teachings, it has become a great school of thought in Islamic mysticism. Development of mystical aesthetic which is based on two axes of "authenticity love" and "authentic beauty" is due to Iranian gentle spirit, sense of taste and the schools' compatibility with the principles of Iranian's Islamic teachings.

Belief in the authenticity of beauty followed by the proof of the creators' beauty through the creation charter makes the love and affection to all particles in the existence profuse and effective. When God is beautiful, whatever he creates is beautiful. Hereafter, every beautiful phenomenon is an indicator of a beautiful creator. According to these verses, "He

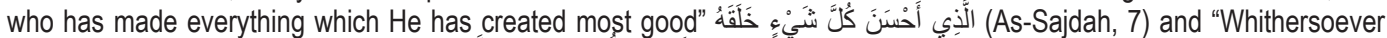

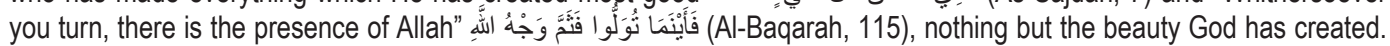
Since Hafez has had a full knowledge of Quran, he employs these verses in his life and considers objective beauty (appearance) as an emanation of absolute beauty-l saw the Lord in the best ostensible emanation رأيت ربي في أحسن صورة (Lahiji, 2010).

This is not only related to Islamic geographical and ritual but rather aestheticisms roots can be found in others schools of thought like the Avesta doctrine. In Visperad, it has been stated that, whatever God has created is good, beautiful, merry, glorious, auspicious and blessed since He is the first origin of all the beauty, glory, wisdom, and blessing. The original source (Ahura Mazda) is all good, thereafter all the existence is created for nothing but pure good. (Emam, 1974)

One of the shared features of all great aesthetic figures, including Hafez, is their reliance on the light, fire, and Moghan's wreckage.

$$
\text { از آن به دير مغانم عزيز مىدارند آه آتشى كه نميرد هميشه در دل ماست }
$$

In the cloister of the magians, me dear they hold for the reason. That, in our heart, a fire that dieth not ever is.

(Hafez, 22)

The combination of aesthetic opinions with Qur'anic wisdom is crystal clear in most of the great figures' works of this school, especially Hafez. This saying is generally popular among them:

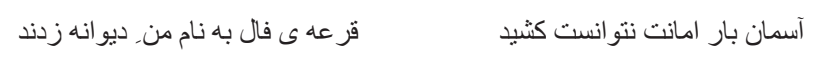

The load of deposit, the sky could not endure: In the name of helpless me, the dice of the work, they cast.

(Hafez, 184)

All beauty, rooted in Aesthetes beliefs, is an emanation of the eternal beloved. That is, part of the manifestation of this beauty leads to the creation of the universe. Other parts unlock the gates of divine names and attributes to the seeker's heart and give them a hand in the process of self-purification. But what are the emanation and beauty? And where do they come from?

As the most famous mystical words and phrases taken from the Quran, the word emanation is derived from Quran as well. Literally, emanation means being smart and visible. As noted, to aesthetics, the world is a manifestation of divine beauty. The word emanation appeares twice in the Quran: once for appearance of the day: "By the Day as it appears in glory" وَالنََّارِ إِذَا تَجَلَّل (Al-Lail, 2) and elsewhere it is used in a sense that is intended by aesthetes: "When his Lord manifested His glory on the Mount, He made it as dust. And Moses fell down in a swoon."

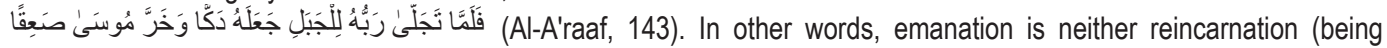
resident in the world of God), nor embodiment (being in human form). Emanation is not lowering output or a gradual loss

${ }^{1} \mathrm{He}$ was originally from Persia, lived in Aleppo and revealed his heretical in Damascus. He was one of the Abahiyeh, but he also believed in God's reincarnation in beautiful people, such that he prostrated before them. Helmanian, the word itself derived from reincarnation 'Holol', is also attributed to Abu-Helman. For further study see: Baghdadi, Abd al-Qahir ibn Tahir. (2006). Al-Fergh- BeinAlfergh. Trans. Mashkor, Mohammd Javad. Tehran: Eshraghi publications. 
of the divine essence; however, it is a victorious, filled with glory emergence of divine attributes in its most exquisite manner which is known as beauty (Shayegan, 2009: 352).

Different types of emanation are cited, including: phenomenal, actions, intrinsic, attributive, beauty-related, glorious, nominal, and etc. (Sajadi, 2008: 223). Hereon, the phenomenal emanation will be explained since it is much more related to the current paper. The phenomenal emanation is a state of perceiving the Almighty God in every aspect of the visible world including corporeal, heavenly and citrus beings (Lahiji, 2010). Among all phenomenal emanations, Formal emanation (i.e. perceiving the Holy beauty of God in Human's form) is the most thorough and prominent emanation.

$$
\begin{aligned}
& \text { مر اد از خط جناب كبريايى است } \\
& \text { كه ازما نبست بيرون خوبرويى } \\
& \text { رخش خطى كثريد اندر خدايى است }
\end{aligned}
$$

Here the face is the manifestation of the divine goodness; the main intention of the sign is indicating the Holy essence of God.

Out of his goodness, he drew an image; indicating that comeliness is in us. (Shabestary, 2009:494)

Therefore, aesthetes not only authorize themselves to appreciate beautiful faces, but also consider the beauty of face as a sign of the Almighty beauty of God. They believe that concepts other than what already mentioned do not deserve love and are even impossible to be loved. Whatever they love is because of its beauty or goodness and no one, other than God, does possess these traits. Since observing the unveiled divine beauty is out of human's patience, the earthly love is a training experience that helps to understand the light of divine beauty. The strength and weakness of the light of divine beauty, in relation to their hearts immaculacy and wisdom, varies in different individuals.

$$
\text { عاثقى كرزين سر و كرزان سر است عاقبت ما را بدان سر رهبر است }
$$

Whether love be form this (earthly) side or from that (heavenly) side, in the end it leads us yonder. (Masnavi, 1: 111)

Originally affection lies in the beauty of the beloved, which is not declining. Rozbehan (1987) stated that: particular individuals have been awarded with special love which is followed by perceiving the beauty. In observing the beauty, one can comprehend the beauty based on his standing since the love mainly originates from observing beauty and goodness.

$$
\begin{aligned}
& \text { حسن روي تو به يك جلوه كه در آينه كرد اين همه نقش در آييهُ اوهام افتاد }
\end{aligned}
$$

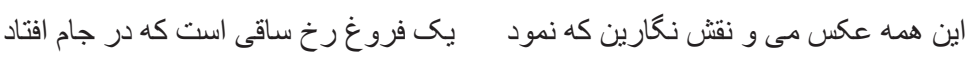

When, into the mirror of the cup, the reflection of Thy face fell, from the laughter of wine, into the crude desire of the cup, the Aref fell.

With that splendor that in the mirror, the beauty of Thy face made, this entire picture into the mirror of fancy fell. (Hafez, 111)

\section{Mystics' Definitions of Beauty}

Shah Nimatullah Wali (2006) states that beauty is the manifestation of Almighty God, to him and for Him. Or it appears when a beloved reveals her perfection because of lover's profound desire and feeling ( Araqi, without date). Aesthetic mystics believe that creation is not without purpose; rather they consider creation as an emanation of eternal beauty which always exists. They also believe in this sacred saying as their proof, I was a hidden treasure, so I loved to I be known, so I created to I be known. اعرف كلى الخلق فخلت اعرف ان فاحبيت مخفيتاً، كنزاً كتب (Forouzanfar, 1991). Thus, divine beauty is a total of His perfection, names and attributes. Since our discussion is concerned with the divine beauty attributes, among all God's names and attributes the present article attempts to explain the beauty traits which are divided into two: 'intrinsic and verbal characteristics' (Razi, 1998). These traits are manifested in the universe and their perfect expression is emerged in human manifestations. 
Therefore, man is beautiful, when he becomes like God. They are all shadows of Haq and the shadow is likened to human"(Sattari, 2000). On this basis,all beauty in the universe (both the beauty of face and character) is related to God. Aesthetic mystics consider apparent beauty a manifestation of divine beauty.

\section{The Elements of Aestheticism}

Like many other schools of thought aestheticism has its own elements. These elements arise from the school's particular perspectives. The school seeks to answer the questions that popped into the mind of human about the creator of the universe, the universe itself and the aims of creation. The most fundamental thoughts of Aestheticism that are love and goodness may be extracted from these responses. In other words, these are two key elements of Aestheticism. Aesthetics unite these two for they believe reaching God and attaining to truth is only possible through love, and goodness is the impetus of love

\section{Beauty}

Beauty is a controversial issue that has so far remained a mystery. Despite all efforts to clarify what one calls beauty, there is still a long way to reach a comprehensive and consistent definition. Tolstoy(1971) mentioned: the word [beauty] is not only unknown, but also since when Baumgarten ${ }^{2}$ established Aestheticism in 1750, a hundred and fifty years ago, till now so many books has been written about beauty by the most capable and empowered men in the world. But the matter still stayed unanswered. Within each new work on aesthetic, the concept of beauty has been solved in a new way. However, mystics and philosophers and so many others never stop striving for a definition of beauty. Each proposes a totally new definition.

In Persian culture, the word 'ziba' is derived from infinitive form 'zibidan', consisting of zib + a (subjective) which is defined as seemly, decent, upright, beautiful, owner of beauty, pleasant, becoming, anything good with grace and beauty. This word also means comeliness which is in contrast with unsightly.

Manicheans believed that God is manifested in every beautiful creature. Beauty is the emanation of the spiritual nature of man (Romanenko, 1973). Such aesthetics can be considered an immediate successor of the mystical theories about beauty which are suggested by Teodor Lipps, Benedetto Croce, or Jacques Martiain. Like feeling love, sensing the nature is a historical matter. Nature, without relation to activity, does not create beauty on its own. Thus, aestheticism without being written or developed, was current among those who worked.

Aesthetics is not exclusively related to human. Some colors and sounds can create happiness both for humans and animals, for instance; female birds can sense the bright colors, beauty, and male birds' delightful singing. So it can be said that beauty has been emerged prior to man, and independent of him. Human, however, can understand and encompass beauty more than any other creatures, perceiving its poetical traits. Thus, the human need for beauty, his aesthetic ${ }^{3}$ need, is all natural and normal which can be considered a common spiritual, moral sense (Jeph roof, 1974). This means that since people have different feeling, therefore their aesthetic needs (although they are innate) appear in various forms, for instance; a beautiful flower excites human's feeling and emotions no matter he is in his early growth or in the space age. However, the emotions' strength, weakness and sort of manifestations are diverse.

Contemplation about beauty also has a history in the Islamic world. In many cases, western philosophers' definitions of beauty were used by Islamic mystics and scholars. Avicenna's considered beauty a combination of discipline, composition and moderation. He believed: love of beauty in the animal soul is instinctive, while love of beauty based on the rational soul is a logic that leads to the perception of beloved adjacency (Avicenna, 1981). In other words, beauty is the perfection. As one gets closer to her/his ultimate perfection, s/he becomes more beautiful. Imam Mohammad Ghazali (1987) also considered the proportionality the main cause of beauty and argued that there is an association between human essence and the superior universe, which is known as the spiritual world. Every beauty, goodness, and appropriateness that is perceptible in this world, as the manifestation of divine beauty, is all as the consequences of beauty, goodness, and proportion of the other universe. Khajeh Ahmad Ghazali also said beloved is a treasure of love and beauty is her/his storage (Ghazali, 2009). Moreover, Adjacency occasionally can be construed as a

${ }^{2}$ The date goes back to the year of writing the text.

${ }^{3}$ The Word aesthetic is derived from the Greek word "aisthetikos", that means receivers'sensitivityandtalentusing theirsenses. Baumgarten called this school of thought a peculiar science; however, it does not mean that he himself established the school. Certainly, one must seek its roots in ancient times (Jeph roof, 1975: 28). 
criterion of beauty. As unity among the components of a poem has great influence on the spirit and makes it beautiful. The above definitions can be divided into the following categories:

1. Beauty can be divided into reasonable and concrete beauty.

2. Concrete beauty is associated with tangibles and reasonable beauty is contributed to mind.

In defining love, which is one of the two fundamental bases of aestheticism, mystics are divided into two groups:

A. Some mystics believe that beauty is created when looking from the perspective of love (Zamani, 2009). This means that creatures' beauty and glory arise from love. This theory has also been proposed in the science of aesthetics. It has been quoted from Tolstoy: beauty does not create love; rather this is love that has created beauty (Niazkermani, 1988). Aesthetics respect this idea, which is known as the agency theory. Advocates of this theory assert when we say something is beautiful, this means that we love it (Beardsley, 2008). According to this view, beauty is a relative matter and each person looks at the concept from his/her own point of view. In his epic "Farhad and Shirin", Vahshi Bafqi explained this concept in the best possible way:
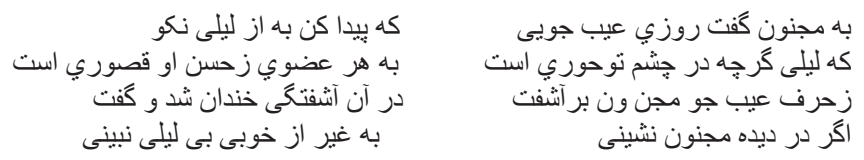

\begin{abstract}
One day, a criticizer asked Majnoon to find a beloved better than Lily.
Although Lily is the apple of your eye, said the caviler; she has so many failures in her goodness.

Majnoon became angry of the cavillar's saying; while being distraught, he smiled and said:

If you put yourself in Majnoon's shoes and see Lily in his eye, you will just find in her the absolute goodness.

(Vahshi Bafqi, 2008)
\end{abstract}

B. However, the aesthetic mystics do not believe this; these mystics consider love a child beauty (Afrasiab pour, 2001). They construed beauty as the obvious emergence of God's greatest attributes (i.e. beauty). God is beautiful and loves beauty as well. Since he is beautiful, he loves to manifest his beauty. Honoring this beauty, hereafter, creates such love and excitement that leads to God's attainment whose beauty, according to aesthetes, is perfect. Refusing to perceive this beauty is considered man's betrayal and disbelief. Since beauty is a fundamental concept of Paradise and doing so ejects God from the Paradise. Thus, beauty is a key attribute of God and the Prophet, Muhammad (PBUH) is a manifestation of God's beauty as a divine human being (Shayegan, 2009). The priority of goodness to love was mentioned in the introduction of Majālis al-'ushshāq, Goodness [older brother] looked at himself, as a great one and became satisfied of himself so he smiled...Love, as a younger brother, was so closed to him and could not take his eyes from him such that he was always an advocate of Goodness (Gazargahi, 1997). These mystics observe the beauty of face, character, and goodness with their common human eye, however to perceive the inner goodness of the intuitive natural sense requires having a sense beyond the natural.

Hafez is among those mystics who sometimes consider love the result of goodness and elsewhere construe love as a requirement for goodness. In either case, however, it is goodness that will set love on fire. Hafez's sonnets are a crystal clear example of aesthetic thoughts. Whenever he speaks of goodness, love appears as its result.

$$
\text { در ازل برتو حسنيت زتجلّى دم زد عشق يبيدا شد و آتش به همه عالم زد }
$$

In eternity without beginning, of glory, the splendor-ray of Thy beauty boasted.

Revealed became love; and, upon the entire world, fire dashed.(Hafez, 152)

This couplet is closely related to the sacred saying of, I was a hidden treasure, so I loved to I be known, so I created to I be known (Forozanfar, 2001). The eternity is a position with no time and place in which there is a Hidden treasure of God's names and attributes "I was a hidden treasure" and goodness is among this treasure of names and attributes. Moreover, the phrase "Thy beauty boasted" is used as an equivalent of "so I loved to I be known, so I created to I be known". "Revealed became love; and, upon the entire world, fire dashed" is an example of manifestation of God's traits in creation "so I create human beings". Creation of human being and emanation of divine attributes in him, therefore, is the secret of creation. Hereafter, love is emerged so that he fell in love with God's eternal beauty. Goodness is generating love and love is the stimuli of creation. In addition, emanation in this couplet is based on intrinsic affection which leads to 
love. In other words, manifestation of the beloved's goodness kindled a fire of love from which not only the wise, deviated man but also pure, holy angels are deprived. Just those who are suffered entered this fire, like Abraham, and become intimate.

The first love ever existed was the love to the beloved. That is, since a beloved is the realization of someone's love, hence the beloved felt a need for lover's love. Here is the level of goodness manifestation and the need for emanation of never-ending goodness in the creature that can accept and tolerate this endless goodness. Here comes the phase of creating love and finally creating the universe so that the eternal goodness has manifestation.

In Mirror for Princess, it is stated that, "after your eyes see the beloved; you will have desire for her. If your hearts prefers, your become tempted to see her again... when you see her for the third time through words, then you are in love and she takes the string" (Wushmgir, 1996).

\section{Love}

A group of Sufis believe that love is aesthetics, which can be perceived but cannot be described. According to this group, none of science, geometry, fancy, imagination and sense and etc can lead us to love. Despite employing all these tools love is still indescribable. Through this path, however, the mystic perceives love on the basis of his understanding, effort and tension. In response to someone who had questioned him about the nature of love, Baha al-Din Valad stated, what can I say, if you found love, and what can I say if you do not?! (Zamani, 2009). This is the same status from which the prophet expressed his cognition incapability. He said before God we did not worship you as you deserve, and we did not comprehend you as it fits you (Majlesi, 1982). This has been far proven to mystics such that they consider their incapability in cognition (i.e. eternal love) their ultimate incapability.

Khajeh Ahmad Ghazali also believed that love is not to express. The adventure of love is beyond words and letters; the tale of love is unspeakable since you can never express its pure and true meanings through letters and words (Ghazali, 2009). Hafez is also among this group of mystics who consider love indefinable:

$$
\text { مشكل عشق نه درحوصله ى دانش ماست حلّ اين نكته بدين فكر خطا نتو ان كرد }
$$

The difficulty of love is not in the capacity of our knowledge: With this thought, the loosening of this subtlety, mistake one cannot make. Hafez, 136)

So many philosophers, traditionally, have contemplated about love in their works and have attempted to provide definitions and classifications. Plato is among these philosophers. He construed that the way of achieving the absolute beauty (God) is: in perceiving beauty do not limit yourself to physical beauty o; rather take it as a ladder through which you go from the first step to second... eventually you will reach all the beauties. In this way, you will find beauty of the soul through beauty of the body. In the end, you will find the beauty of Almighty God (Plato, 2002). Perceiving the absolute beauty of God, according to Plato, is the ultimate goal of human beings and this is not possible except through love. After classifying different type of love in Hafez's work, Khoramshahi divided them into three: a) Human love b) literary love c) divine love (Khoramshahi, 1987). Quoting ftom Mulla Sadra, Khalili has classified different types of human love as follows: 


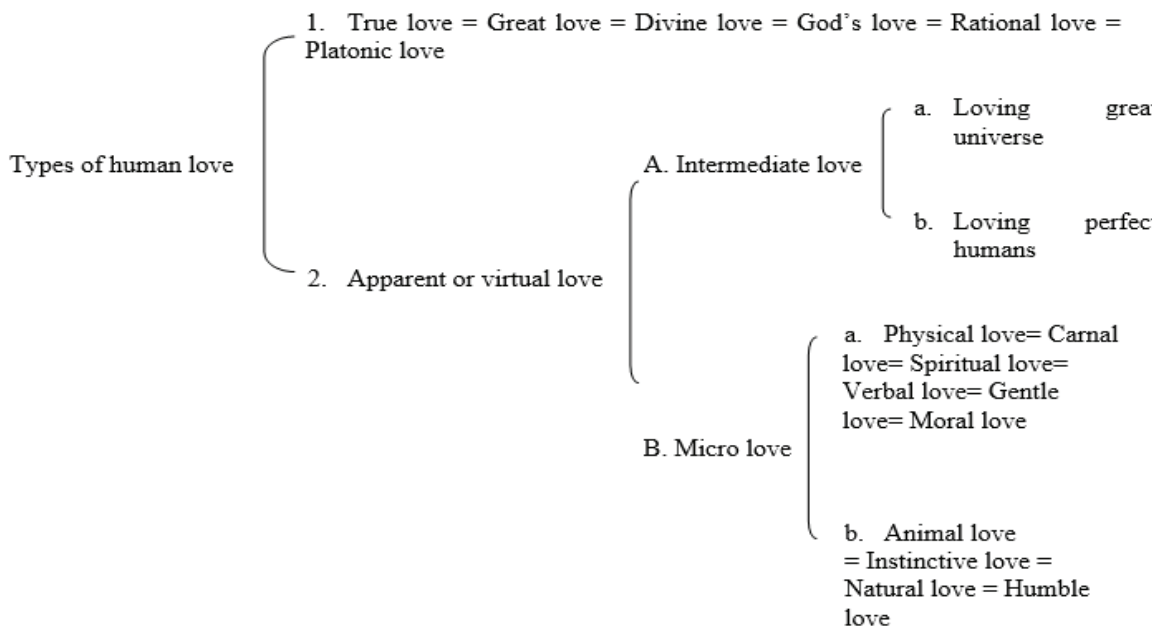

(Khalili, 2009)

Mulla Sadra considered this a comprehensive classification, which encompasses all kinds of human love. Hafez's poems indicate that his mystical love has two dimensions, the beloved pays attention to lovers, and the love among them is ancient. According to his poems, Hafez construes maximum affection as love. Comparing Hafez's poems and thoughts with the above mentioned table, one can conclude that he proudly passes the carnal love and reaches the intermediate love, that is the love of God (perfect man), and eventually achieves true love (divine love).

$$
\text { جان بى جمال جانان ميل جمن ندارد هركس كه اين ندارد حقا كه آن ندارد }
$$

Without the Beloved's beauty, inclination for the world, my soul hath not: O God, everyone who this hath not, that hath not. (Hafez, 126)

\section{Relationship of Love and Beauty}

As already mentioned, Hafez is an aesthete who considers and compares love as the innocent beauty of a child. These mystics summarize the secret of creation and existence in 'love', considering it the basis of these two. Their perspective about the eternal quality of love, its creation, and the eternal God's needs for a beloved who can appreciate his beauty is, love is the result of perception, cognition, and knowledge. Integrating these three along with its domination on beauty and goodness leads to appearance of love (Mortazavi, 1986). Therefore, more goodness leads to more beauty. The stronger and tougher the perception and cognition become, the more powerfully appears the love. Besides, love is always accompanied by perfection and beauty not defect and ugliness. Love is associated with perfection and aestheticism since like his greatness; beauty of the pure essence of God is perfect. Thus, the Almighty God has excessive love to his own beauty, too. In other words, love is founded by means of manifestation of eternal beauty on eternal knowledge. Goodness is like a mine in which love is hidden; the survival of love is dependent upon the survival of goodness. In this vein, the deficits of goodness make a contribution to the deficits of love. The deficits of goodness are created by sin and its consequences affect love. When the sin is far from goodness, however, love appears. This is why the aesthetes stated: at the time when the beam of emanation roused from the soul mountain...it mixed the goodness of eternal and temporal God together (Baqli Shirazi, 1987).

Hence, Divine goodness is considered love's stimuli. Suhrawardi said: Goodness is like a sovereign settled in our being which brings love, sorrow and angels to us (Pourjavadi, 2001). This goodness can be both physical and spiritual. Through passing physical goodness, aesthetics reach spiritual goodness. Since spiritual goodness is absolute and blessed, they consider it superior.

It is crystal clear that God is beautiful, thus he creates beauty. In addition, the desire for beauty is a divine attribute. As the man puts the crown of 'God created humans in his form' on his head, he became a true manifestation of divine beauty. Relying on this statement, "metaphoric love is a bridge and path towards the high levels of love of God for those 
who seek it', Aesthetics focus on human's beauty to find a way of perceiving the truth and preparing themselves to understand the absolute beauty. This is why humans, through the cognitive tools that are being provided, initially understand the form and then perceive the actual meaning.

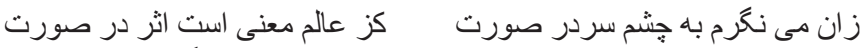

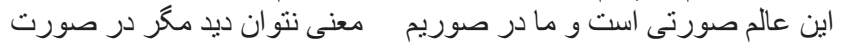

Though I Observe the beautiful face with my ordinary eye; since signs of the world of meaning emerged in the face.

The whole world, in which we are, is indication of His beauty; one cannot perceive the actual truth except by understanding the beauty of the face.(Bayram, 2000)

Hafez also attempts to find both goodness and well being. Goodness is a God's attribute. By loving beloved's beauty, the seeker becomes prepared for understanding and perceiving the unveiled divine beauty. In aestheticism, the power of love is eternal, undeniable force which creates tremendous, boundless power born out of beauty. Ascending such that he only sees God, in the same line, Hafez states:

$$
\text { عالم از شور و شر عشق خبر هيج نداشت فتنه انكيز جهان، غمزة جادوي تو بود }
$$

The universe was not aware of Love's passion and rapture, the whole seditious of the world was based on the Almighty God's coquetry (Hafez 210)

Hafez believes that by passing through a kind of bound beauty, one can achieve the absolute beauty. He considers love his guide without which perceiving the absolute beauty is impossible. Moreover, he does not neglect two threats of analogy and shutting down during this path. It is obvious that love is a form maker i.e. it appears in the concrete manifestations. Inexperienced ones will become fascinated by these concrete manifestations and consider this tension and beauty a result of these concrete forms. Hence, they rely on these forms. The experts of this path, however, believe that each beauty is not a manifestation of itself:

$$
\begin{aligned}
& \text { اين همه نقش در آيينه او هام افتاد } \\
& \text { حسن روي تو به يك جلوه كه در آينه كرد } \\
& \text { يك فروغ رخ ساقى است كه در جام افتاد } \\
& \text { اين همه عكس مى و نقش نـارين كه نمود }
\end{aligned}
$$

With that splendor that in the mirror, the beauty of Thy face made, this entire picture into the mirror of fancy fell.

All this reflection of wine and varied picture that have appeared is a splendor of the face of the Said that, into cup fell. (Hafez, 111)

Here, Hafez again speaks of emanation of divine goodness and asserts that in the mundane mirror of illusion ${ }^{4}$, the emergence of all these enchanting figures, which are like existing non-existence and gremlins, originates from God's goodness.

In this couplet, Hafez believes that all these beautiful pictures and enchanting manifested figures appeared in the universe are all the results of the divine eternal emanations. As the reflection of the beloved beautiful face can create such a beautiful, seductress picture in the wine cup, all these magnificent pictures and figures emanated in different aspects of nature, are the results of God's eternal emanation in the cup; i.e. the universe. Following this manifestation, love is emerged in all creatures and leads distraught Hafez from carnal love to divine love.

$$
\text { طفيل هستى عثقند آدمى و بريري ار ادتى نما تاسعادتى ببري }
$$

Both human beings and angels are the child's of love; thou showst devotion to gain felicity. (Hafez, 452)

${ }^{4} \mathrm{Hafez}$ used the word illusion reflection for mighty world since it manifests illusive figures and picture 
As love is the result of goodness, creation of humans and the universe was the result of love. If it was not for the love of goodness Jinn, Ins, humans, and the universe were not created. According to Hafez, the absolute can only be employed for generous unique God's beauty which its first consequence is love. In a relationship between goodness and love, the distance between the two worlds- human and divine - disappears. One of the most outstanding factors that distinguish between Hafez and other mystics and poets is the great impression he got from goodness and love. This effectiveness can be considered the main characteristics of Hafez's mysticism, such that this effectiveness is become vivid just by looking at his sonnets. He himself confirms that what first brought him to the valley of love and attracted him to the beloved was his love of divine beauty manifestations.

$$
\text { جه خوش صيددلم كردي بنازم جشت مستت را كه كس آهوي وحشى را از اين خوشتر نمى كيرد }
$$

In respect of our need and of the independence of the true Beloved, is speech

O heart! What profit sorcery, when in the Heart-Ravisher, it taketh not. (Hafez, 149)

Elsewhere he states:

$$
\text { بيخود از شعشعهُ بِرتو ذاتم كردند باده از جام تجلّى صفاتم دادند }
$$

Through the effulgence of the ray of His essence, me senseless, they made: From the cup of splendor of His qualities, me wine they gave. (Hafez, 183)

The second hemistich of this couplet refers to emanation of the Almighty God's beauty attributes. 'Giving wine' is interpreted as 'God's manifestation through his attributes.' Since its results are succoring, it can be said that this is an emanation of God's beauty not a manifestation of his greatness traits. As a result of emanation of God's beauty attributes, a passion for love will appeare

The emergence of these attributes in Hafez's sonnets has various manifestations. One of these attributes is the appearance of ' $I$ ' which includes all those beauty attributes that are indescribable. Among his sonnets, there are two different types of coquetry, namely the goodness coquetry and the beloved's coquetry (Pourjavadi, 2001), indicating his belief to aestheticism. Goodness coquetry is vivid in all phenomenal manifestations i.e. goodness is always visible in the universe. In formal emanation, as we said, the eternal beauty manifested in the beautiful faces, this can be considered the stage of goodness coquetry. After perceiving the beauty by the lover and beloved and adding cute affectation to the goodness coquetry, however, love of goodness will be created and a new phase of beloved's coquetry begins. Thus, in goodness coquetry there is no need for beloved, while in the beloved's coquetry there is a crucial need for both love and lover. This leads to the conclusion that every beauty has goodness coquetry in itself. Only man includes the beloved's coquetry. In Hafez sonnets, 'If' refers to this kind of beloved's coquetry which leads to love. The beloved needs this coquetry to become acceptable and create love. Not because of his failure but rather because of his cleverness, Hafez explains this point through his poetic language.

$$
\text { شاهد آن نيست كه مويى و مى انى دارد بندة طلعت آن باش كه آنى دارد }
$$

That one is not the beloved, who hath a hair and a waist: Be the slave of the form of that one who, ravishingness to the highest degree, hath. (Hafez, 125)

Based on Eastern ontology, there is only one genuine, authentic truth in the universe and the rest are various manifestations and diverse expressions of that unique truth, "To Allah belong the east and the West: Whithersoever you

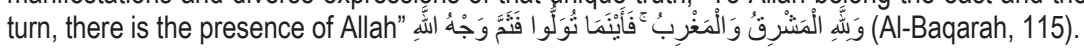

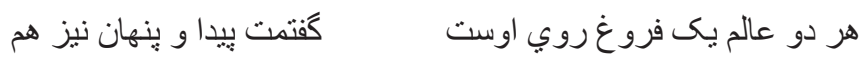

Whatever you see in both universes are the results of God's presence; revealing both hidden and visible truth.(Hafez, 363) 
Aesthetics, including Hafez, believe that grandstanding and ostentation are crucial elements of every beauty, perception of which is the main motivation and operation of love. More beauty appears as the perception becomes stronger. Therefore, it is indicated that God initially emanated on himself and loved himself. Since there is no greater perception and beauty than God, thus, the true lover and true beloved is the holy essence of God himself. According to Hafez, the foundation of universe is based on love and God's eternal beauty is the main reason of its creation. Manifestation and beauty are interdependent, while emanation and grandstanding are essential for beauty. On the other hand, existence of stands and symbols are the requirements of manifestation and presentation. So, in his perspective, goodness and love are the reason of creation. With all its diversity, the universe is originated from God's beauty and affection; i.e. if it were not for his divine goodness, aptitude, affection, and motivation of love, no creature was born and his love would not spread in all around the universe. Hence, goodness and beauty are interdependent with manifestation and love.

$$
\text { حسن بى بايان اوجندا نحةه عاشق مى كثد زمره اي ديكر به عشق از غيب سر برمى كنند }
$$

As much as his boundless beauty slayeth the lover, from the invisible, their head in love, raised another crowd make. (Hafez, 199) or:

$$
\text { عالم از شور و شر عشق خبر هيجز نداشت فتنه انكيز جهان غمزة جادوي نو بود }
$$

The universe was not aware of Love's passion and rapture, the whole seditious of the world was based on the Almighty God's coquetry.(Hafez, 210)

\section{Conclusion}

With regard to what is already discussed, one can conclude that in Hafez's sonnets, crystal clear example of aesthetics' thought, love appears whenever he speaks of goodness. Love and goodness are two fundamental elements of aestheticism, absence of each can create deficit.

According to Hafez, describing unseen Joseph is inefficient, while he can be seen through the visionary eyes. Hafez, however, is vigilant that nothing penetrates in his honest love. In his viewpoint, the absolute goodness is specific of God's unique beauty and its first outcome is love. In the relationship between goodness and love, distance between the two worlds - human and divine - disappears. At the end, this indescribable beauty can be considered the beloved's coquetry, through which beauty is manifested to the lover's heart.

\section{References}

Afrasiab pour, Ali Akbar. ( 2001). Aestheticism in Islamic Mysticism, 1st Edition. Tehran: Tahouri Publication.

Araqi, Fakhr al-dīn Ibrahīm. (without date). Kulliyat-e Araqi, Margin and Suspensions. Darvish. \& Nafisi. Tehran. Javidan Publication.

Avicenna, Hosein Ibn Abdulah. (1981). Avicenna's Philosophical Works. Translated by Zia al-Din Dorri. Tehran: Markazi Publication.

Bafqi, Vahshi. ( 2008). Divan-e Vahshi Bafqi, Attempted by Parviz Babaii, 6th Ediion. Tehran: Negah Publication.

Baqli Shirazi, Roozbahan. (1987). Abharol Ashiqin. Edited by Corbin. H. \& Moin. M. 3rd Edition. Tehran: Manouchehri Publication.

Bayram, Michael. (2000), Auhaduddin Kermani and The movement of Ahaddie, Trans: hoseini, M. \& Vafaii. D., 1st Edition, Tehran: Markaz Publication.

Beardsley, Monroe. \& Hospers, John. (2008). Aesthetics: A Short History, Translated by Saiid Hanaii Kashani, 2nd Edition. Tehran: Hermas Publication.

Emam, Muhammad Kazim (1974). Philosophy of ancient Iran and The principles of Hikmat al-Ishraq (thought, work and history of the life of Sohrawardi). Tehran, Nouriani Charity Organization.

Forouzanfar, Badiuzaman. (1991). HadithMasnavi, 5th Edition. Tehran. Amir Kabir Publication.

Gazargahi, Amir Kamaleddin Hosein. (1997). majalesoloshagh, Attemted by Gholamreza Tabatabaii Majd, 2nd Edition. Tehran: Zarin Publication.

Ghazali, Abu Hamed Muhammad. (1987). Revival of Religious Sciences. Translated by Muhammad Kharazmi. 2nd Edition. Tehran: Elmi Farhangi Publication. 
Ghazali, Ahmad. (2009). Sawaneh, 1st Edition. Tehran: Sales Publication.

Hāfez, Shamsu d-Dīn Muhammad (1995). Edited by Ghazvini \& Ghani. 5th Edition. Tehran: Asatir Publication.

Khalili, Mohammad Husein. (2009). Philosophical Foundations of Love (in Avicenna and Mulla Sadra's perspective). 3rd Edition.

Tehran: Bustan Ketab Publication

Khoramshahi, Baha'eddin. (1987). Hafiz Namah. 1st Edition. Tehran: Soroush Publication.

Lahiji, Shaykh Muhammad (2010). Mafatih al 'ijaz fi sharh-e Golshan-e raz, Edited by Mohammad Reza Barzegar \& Efat Karbasi. 8th Edition. Tehran: Zavar Publication.

Majlesi, Mohammad Baqir. (1982). Oceans of Light. 3rd Edition. Beirout: Dar al-kutub al-'ilmiyya.

Molavi, Jalal al-din MohamadBalkhi. (1999).MasnaviMa'navi, edited by Abd al-karinSoroush, 5th edition.Tehran: Scientific and Cultural Press.Rozbehan.

Mortazavi, Manuchehr. (1986). The School of Hafiz. 2nd Edition. Tehran: Tus Publication.

Niazkermani, Saeed. (1988). Hafiz Shenasi, Volume II. Tehran: Pajang Publication.

Plato. (2002). Symposium. Trans. Sanaii. M. Edited by Jahanbakh. F. Tehran: Farhang.

Pourjavadi, Nasrullah. (2001). Shinning and Mysticism (Articles and critics), Tehran: Daneshgahi Publication.

Razi, Najm al-din.(1998).Mersad al-ebad, edited by Amin Riahi, Tehran: Scientific and Cultural Press.

Romanenko, Silaf, Stanf et al. ( 1973). New Aesthetics, Trans: Partovi, M., Tehran: Amir Kabir Publication.

Roof, Jeph. (1974), In Understanding art and beauty, trans: Sadiq, H., 1st Edition. Tehran; peivand Publication.

Sajadi, Seyed Jafar. (2008). A Glossary of Mystical Terms and Interpretations, 8th Edition. Tehran: Tahoori Publication.

Sattari, Jalal. (2000). The Union of Love between East \& West. 2nd Edition. Isfehan: Farda Press

Shabestary, Mahamoud. (2009). Garden of Mystery, an introduction by Mahmoud Sani,Tehran: Maharat Publications.

Shayegan, Darioush.\& Corbin,Henry. (2009). The spiritual topography of Iraniam Islam, Translation of Parham, B. 5th Edition.Tehran: Forouzan Publication.

Tolstoy, Leo. (1971). What Is Art?, Translated by Kaveh Dehgan. 3rd Edition. Tehran: Amir Kabir Press.

Wali, Shah Nematollah. (2006). The Epistles of Shah Nematollah Wali, Edited by Javad Nourbakh. Tehran: Bita Publication.

Zamani, Karim. (2009). Minagar-e 'Eshq, 7th Edition. Tehran: Nay-Nil Publication.

Wushmgir, Onsor alma'li Keikavous Ibn-Iskandar. ( 1996). The Lessons of Life ( Collection of Qabus-Namah), 3rd Edition. Tehran: Sokhan publication. 
